\title{
DDX20 Gene
}

National Cancer Institute

\section{Source}

National Cancer Institute. DDX20 Gene. NCI Thesaurus. Code C118355.

This gene is involved in catalyzing the assembly of small nuclear ribonucleoproteins. 